\title{
Strategies for Chemical Control of Root-knot Nematodes (Meloidogyne spp.) in Established Vineyards ${ }^{11}$.
}

\author{
J.T. Loubser ${ }^{\mathrm{a})} \&$ A.J. Meyer ${ }^{\mathrm{b})}$ \\ a) Viticultural and Oenological Research Institute, 7600 Stellenbosch, Republic of South Africa. \\ b) Department of Entomology, University of Stellenbosch, 7600 Stellenbosch. \\ Submitted for publication: July 1986 \\ Accepted for publication: August 1986 \\ Keywords: Control, Meloidogyne, Root-knot, Nematodes, Vineyards, Root Distribution
}

\begin{abstract}
Grape-vine root growth was measured for vertical and horizontal distribution as well as seasonal growth periods. The persistance of aldicarb and fenamiphos in the soil as well as in leaves and fruit of grape-vines was monitored over a prolonged period to establish behaviour patterns which influence chemical control strategies. Most roots occurred within $600 \mathrm{~mm}$ from the trunk, both vertically and horizontally. Two periods of root development occurred annually. Accordingly applications of nematicides should be made in a band covering $600 \mathrm{~mm}$ on both sides of the vine trunk, either after harvest and/or during budburst. Results on residues of aldicarb and fenamiphos stress the importance of adequate water supply after application. Both nematicides will reach the bulk of the roots if correctly placed and were still detected after $\mathbf{4 2}$ days and 70 days respectively. Applications during spring with aldicarb and fenamiphos at the dosages used will have no effect on the fermentation of grape musts nor result in toxic residues exceeding $0,05 \mathrm{mg} / \mathrm{kg}$ in the grapes.
\end{abstract}

Many commercial grape-vine rootstocks are susceptible to root-knot nematodes (Meloidogyne spp.), necessitating the need for effective chemical control. Since the withdrawal of DBCP (1,2-dibromo-3-chloropropane) in 1977, several alternatives have been tested with varying degrees of success (Rajendran \& Naganathan, 1978; ATILANO \& Van Gundy, 1979; Cuany et al., 1979; Cuany, Lavergne \& Pistre, 1980; Raski et al., 1981; Stirling, 1982; Loubser \& De Klerk, 1986). Logically the aboveground response to nematode control will take longer to be expressed in the case of a perennial crop. This, together with the inherent variation in growth between vines, makes consistency of results in experiments on control an ambitious goal.

Nematode control by the carbamate and organophosphate nematicides does not necessarily involve direct killing, but rather the inhibition of certain functions such as hatching, movement, orientation, infestation and development of the nematode (Nelmes \& Keerweewan, 1970; Homeyer, 1971; Hough \& Thomason, 1975). These functions are inhibited at different concentrations and exposure times of a nematicide and in some cases recovery is possible if exposure is of limited duration.

The fate of aldicarb and fenamiphos in soil and plants has been studied by several workers and it was shown that the physical properties of both the soil and the nematicide play an important role in the distribution of these nematicides and consequently the efficiency of nematode control (Andrawes, Bagley \& Herrett, 1971; Bromilow, 1973; Hafez \& Raski, 1981; Hofmeyer \& Wagner, 1981). Hough, Thomason \& Farmer (1975) indicated that the behaviour of soil-applied pesticides is largely governed by the adsorption characteristics of the soil. Although this may be an important factor, poor nematode control may also be attributed to the method of applying the nematicide (Whitehead, 1973) or to inadequate soil moisture (Griffin, 1978).

Root-knot nematode larvae usually penetrate near the root tip. New root growth in grape-vines normally occurs early in the growing season (spring) while limited rooting also occurs after harvest (Pratt, 1974; Freeman \& Smart, 1976; Conradie, 1980; McKenry, 1984). Consequently, whenever nematode control is attempted, effective applications would be achieved only if the nematicide is present in the soil profile when and where most roots are found. Den Ouden (1971) has shown that Heterodera rostochiensis larvae are repelled from roots of potatoes previously treated with aldicarb or fenamiphos. However, development of larvae which had already penetrated the roots was not affected when roots were treated eleven days after they had been invaded. This may also be the case with Meloidogyne spp. in grape-vine roots. Timing of application may therefore be critical for the protection of newly formed roots.

When all possible factors which can influence the efficiency of nematode control by a specific nematicide are considered, it is evident that the predictability of success is limited. This problem can only be overcome by experimentation, experience and a sound knowledge of the host/parasite interactions.

In the present study grape-vine root distribution, as well as the periods of root development, was determined for an established vineyard. Movement and persistance of aldicarb and fenamiphos were also monitored in the soil as well as in the host plant. This was done in order to determine the optimum timing and placement of a nematicide which would enhance nematode control.

1.) Part of a thesis to be submitted by the senior author to the University of Stellenbosch for the Ph.D. (Agric.) degree.

Thanks are due to Me Krause at the Plant Protection Research Institute who performed all analyses for aldicarb and fenamiphos, and to the Soil and Microbiology Sections at VO R I for soil and grape must analyses respectively. 


\section{MATERIALS AND METHODS}

\section{A. Root Distribution:}

Vertical and horizontal distribution of vine roots in the Vaalharts irrigation area, Northern Cape, was determined on Colombar vines grafted onto 99 Richter in a loamy sand with a planting width of $3,75 \times 1,5 \mathrm{~m}$.

For the determination of vertical distribution a $600 \mathrm{x}$ $600 \mathrm{~mm}$ area between the rows, directly next to the trunk of each of five randomly chosen vines, was excavated in layers of $150 \mathrm{~mm}$ to a depth of $1,2 \mathrm{~m}$. All fine roots $(\leqslant 5 \mathrm{~mm} \emptyset)$ were sieved from this soil and fine root distribution with depth was calculated on a wet mass and percentage basis.

For the determination of horizontal fine root distribution between rows, a hole was dug $1,2 \mathrm{~m}$ from the trunk of each of five randomly chosen vines to a depth of $1,2 \mathrm{~m}$ and a width of $600 \mathrm{~mm}$. Soil was then removed in vertical sections of $300 \mathrm{~mm}$ over the full depth of the hole towards the vines and all fine roots $(\leqslant 5 \mathrm{~mm} \emptyset)$ were removed by sieving through a $10 \mathrm{~mm}$ sieve. Horizontal root distribution was calculated as for vertical distribution.

\section{B. Root Growth Periods:}

In order to establish the time of root development of grape-vines at Vaalharts, two underground observation chambers similar to that described by Van Zyl (1984) were made. A hole was dug in the middle of two vine rows and the frames were installed $450 \mathrm{~mm}$ from the vines observed at an angle sloping downwards towards the vines and supported by brickwork. The observation chambers were installed during spring and first recordings regarding root growth were made in summer of the next year. Root growth was recorded at weekly intervals for twelve months by counting the number of wire grids in the glass which were intersected by newly developed vine roots. Strict weed control was maintained around the observation chambers to avoid confusion between weed and vine roots.

Soil temperatures at $300 \mathrm{~mm}$ depth were recorded on a continuous basis for the duration of the observation period.

\section{Movement and Persistance of Nematicides:}

Two chemicals, viz. aldicarb $15 \%$ gran. and fenamiphos $10 \%$ gran., were used. Both were applied in two bands on either side of the vine row, each band being $300 \mathrm{~mm}$ from the vines. The bands were either $200 \mathrm{~mm}$ or $1 \mathrm{~m}$ wide. Aldicarb was applied at a rate of $5 \mathrm{~g} / \mathrm{m}$ and fenamiphos at $20 \mathrm{~g} / \mathrm{m}$. Three replicates consisting of ten adjacent vines each were treated during spring, one week after budburst. The chemicals were incorporated into the top $100 \mathrm{~mm}$ of soil with a disc and plots were flood irrigated (ca. $40 \mathrm{~mm}$ water) immediately after application.

For residue analyses, composite soil samples from a depth of $100-300 \mathrm{~mm}$ and $400-600 \mathrm{~mm}$, as well as composite leaf and fruit samples, were collected at various stages from each replicate of the band applications. Because of limited analytical facilities, only leaf samples were analysed in the case of strip applications. Aldicarb and fenamiphos residues were quantified according to the methods of Carey \& Helrich (1970) and Hild \& Thier (1978) after oxidation to aldicarb sulphone and fenamiphos sulphone respectively. Fruit samples were analysed for residues 29 days, 15 days, 8 days before, as well as at harvest, by using the same methods. Details of analytical techniques are discussed by Krause, Loubser \& De Beer (1986). Musts from treated and untreated vines were also subjected to standard V O R I fermentation tests in order to determine possible effects of nematicide residues.

\section{Soil Texture:}

Soil texture was determined to a depth of $1,2 \mathrm{~m}$ by implementing standard V O R I techniques and using the samples taken for vertical root distribution. Sand, silt and clay fractions were determined in order to identify any textural changes which may influence root distribution or nematicide movement in the soil. Soil $\mathrm{pH}$ was determined in 1:25 $\mathrm{KC} 1$.

\section{RESULTS AND DISCUSSION}

\section{A. Root Distribution:}

Approximately $50 \%$ of fine roots of 99 Richter were concentrated in the top $300 \mathrm{~mm}$ of soil (Table 1). The top $600 \mathrm{~mm}$ of soil yielded $75 \%$ of all fine roots.

Almost half $(46 \%)$ of all horizontally distributed fine roots were found within $300 \mathrm{~mm}$ of the vine trunk and $71 \%$ within $600 \mathrm{~mm}$.

\section{TABLE 1}

Fine root distribution of 99 Richter in a loamy sand at Vaalharts.

\begin{tabular}{r|r|r|r}
\hline \multicolumn{2}{c|}{ Vertical distribution } & \multicolumn{2}{|c}{ Horizontal distribution } \\
\hline depth $(\mathrm{mm})$ & $\%$ & distance $(\mathrm{mm})$ & $\%$ \\
\hline $0-150$ & 25 & $0-300$ & 46 \\
$150-300$ & 25 & & \\
\hline $300-450$ & 15 & $300-600$ & 25 \\
$450-600$ & 10 & & \\
\hline $600-750$ & 6 & $600-900$ & 17 \\
$750-900$ & 8 & & \\
\hline $900-1050$ & 6 & $900-1200$ & 12 \\
$1050-1200$ & 5 & & \\
\hline
\end{tabular}

Root distribution of grape-vines will obviously differ from one locality to another and may be influenced by several factors. However, from the results obtained by McKenry (1984), root distribution of Thompson seedless and Ramsey was essentially similar and ca. $60 \%$ occurred in the top $600 \mathrm{~mm}$ of soil.

These findings stress the importance of nematicide applications in the row rather than between rows. It also indicates that the nematicide should be leached downwards to a depth of at least $600 \mathrm{~mm}$ in order to be effective.

\section{B. Root Growth Periods:}

Periods of active root growth for 99 Richter, as well as average monthly soil temperatures at $300 \mathrm{~mm}$ depth at Vaalharts, are shown in Figure 1.

Two root growth periods occurred during the year. Root growth was first detected after harvest (February) and lasted until the beginning of July (16 weeks). Peak root growth was measured during March declining with temperature to reach a minimum in July. The second and major growth period was recorded from September to January ( 21 weeks) with a maximum in October. 
AVERAGE SOIL TEMPERATURE AT $300 \mathrm{~mm}$ DEPTH $\left({ }^{\circ} \mathrm{C}\right)$

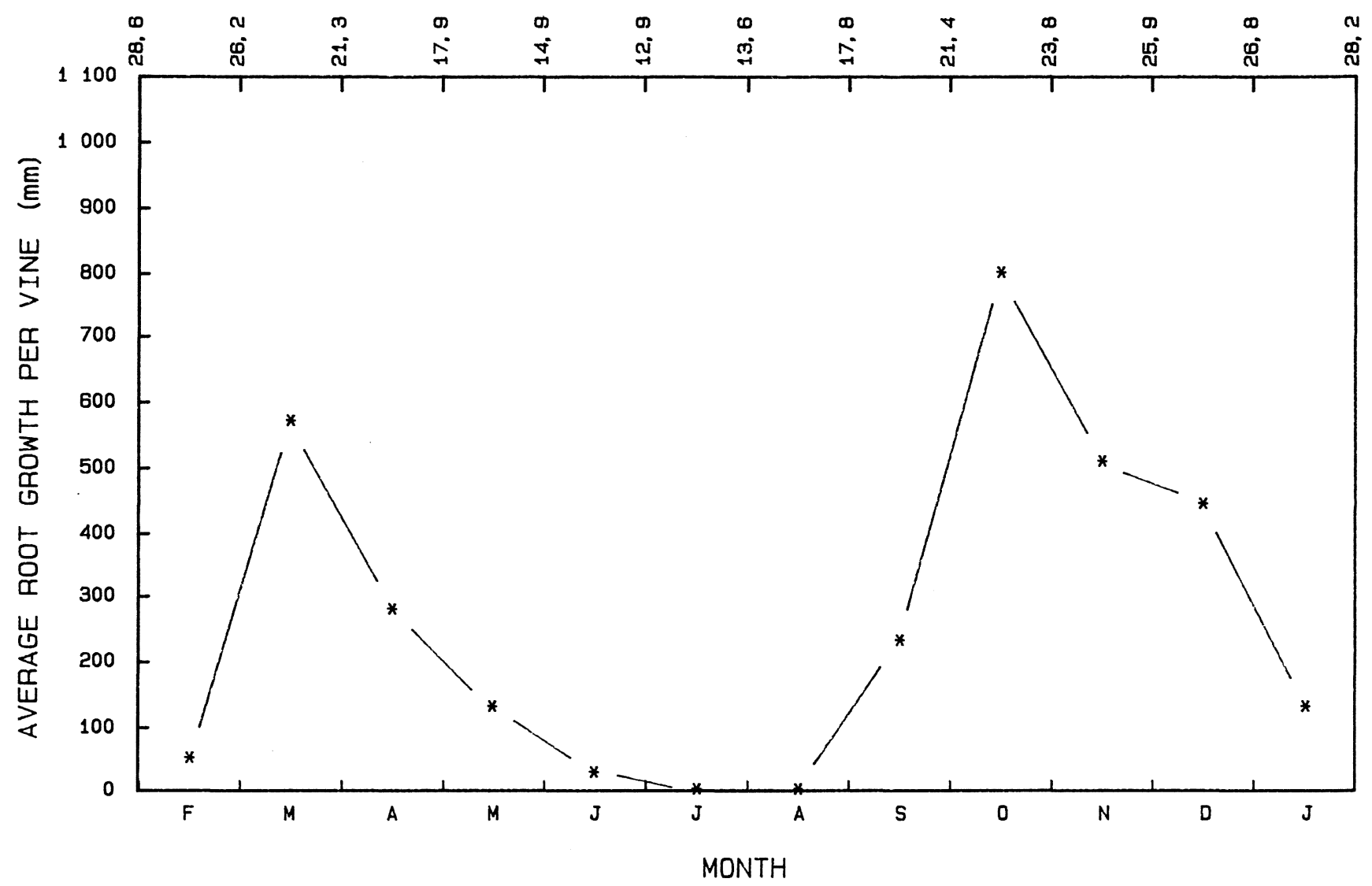

FIG. 1

Periods of active root growth of Colombar/99 Richter in a loamy sand at Vaalharts.

This is in agreement with results of Freeman \& Smart (1976) and McKenry (1984). In order to protect newly formed roots from nematode infestation, it is obvious that treatments should take place during these two periods. Onset of root growth is important if inhibition of penetration of the roots by the nematode is to be achieved. The first root growth in spring was detected four weeks before budburst (20 September) with soil temperature at $15^{\circ} \mathrm{C}(300 \mathrm{~mm}$ depth). These findings were also confirmed during the following year. However, according to Richards (1983) and others, root growth of grape-vines commences about three weeks after budburst. Soil temperatures are considered to play an important role in this regard and therefore fur-

TABLE 2

Aldicarb residues in soil, grape-vine leaves and fruit following soil treatment during spring*.

\begin{tabular}{|c|c|c|c|c|c|c|}
\hline \multirow[b]{2}{*}{$\begin{array}{c}\text { Days } \\
\text { after } \\
\text { application }\end{array}$} & \multirow[b]{2}{*}{$\begin{array}{l}\text { Rainfall/ } \\
\text { Irrigation } \\
\text { (mm) }\end{array}$} & \multicolumn{5}{|c|}{ Average aldicarb sulphone $(\mathrm{mg} / \mathrm{kg}$ ) of three replicates ( 30 vines) } \\
\hline & & $100-300 \mathrm{~mm}$ & $400-600 \mathrm{~mm}$ & (A) & (B) & $\begin{array}{r}\text { Frui } \\
\text { (A) }\end{array}$ \\
\hline 0 & - & 0 & 0 & 0 & 0 & - \\
\hline 1 & 40 & 0,42 & 0,13 & 0 & 0 & - \\
\hline 3 & 0 & 0,28 & 0,26 & 0,29 & 0,67 & - \\
\hline 7 & 0 & 0,19 & 0,35 & 0,97 & 7,14 & - \\
\hline 10 & 0 & - & - & 1,28 & 6,11 & - \\
\hline 14 & 30 & 0,39 & 0,54 & 1,06 & 5,97 & - \\
\hline 28 & 22 & 0,24 & 0,42 & 9,03 & 5,93 & - \\
\hline 42 & 0 & 0,16 & 0,37 & 11,85 & - & - \\
\hline 70 & 163 & 0 & 0,03 & 0,91 & - & - \\
\hline 112 & 124 & - & - & 0,36 & 0,22 & 0,04 \\
\hline 126 & 0 & - & - & - & - & 0,03 \\
\hline 133 & 0 & - & - & - & - & 0,01 \\
\hline 141 & 0 & - & - & - & - & 0,01 \\
\hline
\end{tabular}

A. One metre band application.

B. $200 \mathrm{~mm}$ strip application.

*For more detailed information on these aspects see Krause et al. (1986). 
ther investigations in other vinegrowing areas are necessary. These will supply information concerning the correct timing of application for different areas.

\section{Movement and Persistance of Nematicides:}

Aldicarb recorded in soil, grape-vine leaves and fruit at different times after application is shown in Table 2.

Aldicarb was detected in soil samples taken at $100-300 \mathrm{~mm}$ and $400-600 \mathrm{~mm}$ depths within one day following treatment. Aldicarb lasted for 70 days after reaching a peak within 14 days. Downward movement of the nematicide was good and higher rates were detected at $400-600 \mathrm{~mm}$ than at $100-300 \mathrm{~mm}$ depth, seven days after application. Heavy rains between days 42 and $70(163 \mathrm{~mm})$, may have resulted in total leaching of aldicarb from the upper zone. On the other hand, approximately 70 days are required for total breakdown of aldicarb in soil (Andrawes et al., 1971; Iwata et al., 1977).

These results show that nematode control within the major root zone can be achieved almost immediately if aldicarb is washed downwards by irrigation. A relatively constant amount of aldicarb will remain in this zone for at least 42 days.

Aldicarb sulphone in grape-vine leaves was detected three days after treatment for both application methods, whereas peak concentrations for strip and band applications were reached after seven days and 42 days respectively. Residues for both these treatments were recorded for a period of 112 days following application and at this stage concentration levels were about the same. Heavy rainfalls preceded the last two observations and might have influenced the level of residues at days 70 and 112 .

Leaf residues, substantially higher than that of soil samples, were recorded and this illustrates the efficient acropetal translocation of aldicarb. Strip application resulted in higher levels of the nematicide in the leaves than did band applications for the first fourteen days. Both these findings will have practical implications when nematode control strategies are planned. If high leaf residues are indicative of high nematicide concen- trations in the roots, it is obvious that strip application will have a more rapid effect on nematodes than band application. This will influence the timing of application. However, according to technical reports (Union Carbide, unpublished data) the basipetal translocation of aldicarb within plants is limited. If translocation within the root system of a treated vine is poor, the method of application will have to be adjusted according to a specific situation in order to bring the nematicide in contact with as many roots possible. According to Hough et al., (1975), the horizontal movement of aldicarb in soil is limited and dependent on soil type. Applications which include the berm (See A above), may therefore be necessary for maximum vine root contact under flood irrigation. Strip application (including the berm) may, on the other hand, be effective on micro-or drip-irrigated vineyards which have a more confined root system.

Residues in fruit 29 days before harvest were $0,04 \mathrm{mg} / \mathrm{kg}$, but this declined to $0,01 \mathrm{mg} / \mathrm{kg}$ at time of picking. This is within the accepted tolerance level $(0,05 \mathrm{mg} / \mathrm{kg})$ and applications during spring can therefore be recommended.

Fenamiphos was detected in soil samples taken at both depths within one day after application (Table 3 ). The high fenamiphos residues at $600 \mathrm{~mm}$ depth show that this nematicide can be washed down to the deeper level if sufficient water is supplied during application. Residues at $600 \mathrm{~mm}$ depth were high at day one and thereafter remained low compared to the $300 \mathrm{~mm}$ depth. This might be attributed to migration of the pesticide to the upper layers. Increasing residue levels at the $300 \mathrm{~mm}$ depth support this possibility. At 70 days, when soil analyses were terminated, fenamiphos residues were still very high, suggesting a longer residual action in soil than aldicarb at the dosages used. The figures recorded for day 70 seem to correspond with observations made by Hofmeyer \& Wagner (1981). They found that fenamiphos leaches slowly and that residues remained in the topsoil even after 84 days. The effect of leaching can be seen by the higher figure obtained at the deeper level on day 70 compared to day 42 . Be-

TABLE 3

Fenamiphos residues in soil, grape-vine leaves and fruit following soil treatment during spring*

\begin{tabular}{|c|c|c|c|c|c|c|}
\hline \multirow[b]{2}{*}{$\begin{array}{c}\text { Days } \\
\text { after } \\
\text { application }\end{array}$} & \multirow[b]{2}{*}{$\begin{array}{l}\text { Rainfall/ } \\
\text { Irrigation } \\
(\mathrm{mm})\end{array}$} & \multicolumn{5}{|c|}{ Average fenamiphos-sulphone (mg/kg) of three replicates (30 vines) } \\
\hline & & $100-300 \mathrm{~mm}$ & $400-600 \mathrm{~mm}$ & (A) & (B) & $\begin{array}{l}\text { Fruit } \\
\text { (A) }\end{array}$ \\
\hline $\begin{array}{r}0 \\
1 \\
3 \\
7 \\
10 \\
14 \\
28 \\
42 \\
70 \\
112 \\
126 \\
133 \\
141 \\
\end{array}$ & $\begin{array}{r}\overline{-} \\
40 \\
0 \\
0 \\
0 \\
30 \\
22 \\
0 \\
163 \\
124 \\
0 \\
0 \\
0 \\
\end{array}$ & $\begin{array}{l}0 \\
0,38 \\
1,24 \\
1,39 \\
- \\
2,12 \\
2,71 \\
2,89 \\
2,24 \\
- \\
- \\
- \\
-\end{array}$ & $\begin{array}{l}0 \\
2,75 \\
0,79 \\
0,28 \\
- \\
0,19 \\
0,07 \\
0,35 \\
2,04 \\
- \\
- \\
- \\
-\end{array}$ & $\begin{array}{l}0 \\
0 \\
0 \\
0 \\
0,05 \\
0,09 \\
1,45 \\
0,80 \\
0,93 \\
0,54 \\
- \\
- \\
-\end{array}$ & $\begin{array}{l}0 \\
0 \\
0 \\
0 \\
0 \\
0,07 \\
2,93 \\
- \\
- \\
- \\
- \\
-\end{array}$ & $\begin{array}{l}- \\
- \\
- \\
- \\
- \\
- \\
- \\
- \\
0,03 \\
0,02 \\
0,01 \\
0,02\end{array}$ \\
\hline
\end{tabular}

A. One metre band application.

B. $200 \mathrm{~mm}$ strip application.

${ }^{*}$ For more detailed information on these aspects see Krause et al. (1986). 


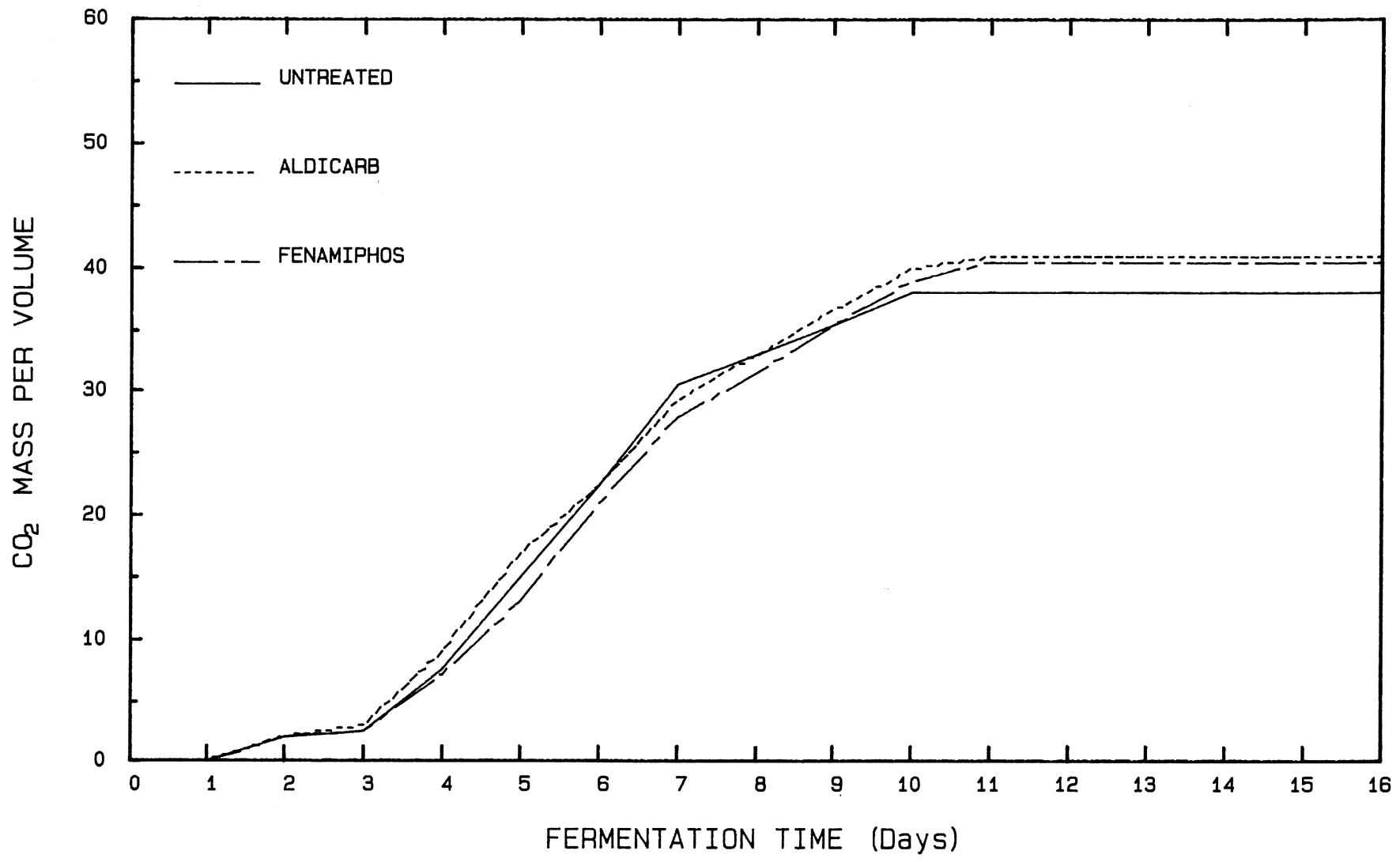

FIG. 2.

Fermentation of grape must from aldicarb and fenamiphos treated as well as untreated grape-vines.

cause of the lower solubility of fenamiphos (Hafez, Raski \& Lear, 1981) more rain or irrigation following treatment would also have resulted in higher concentrations at deeper levels during earlier stages. The importance of an adequate irrigation following treatment is therefore evident.

Fenamiphos metabolites were detected in grape-vine leaves only after ten and 14 days for the two application methods used. This was later than for aldicarb, suggesting a slower uptake, most probably because of the lower solubility of this chemical. Residues in leaves remained relatively constant for 112 days following treatment. No analyses were performed for later dates.

Because of the delayed systemic action and slower leaching of fenamiphos, this nematicide should be applied at an earlier date than aldicarb. Data on leaf residues of bands and strip applications are inadequate, but it seems as if the rate of nematicide uptake by the plant is not influenced by the method employed. Basipetal translocation of fenamiphos in plant tissue is good (Flint, 1977) and strip treatments with this nematicide may therefore be equally effective as band applications. This too, was not determined in the current trial.

Residues in fruit at the time of picking were $0,02 \mathrm{mg} / \mathrm{kg}$ which is also within the acceptable tolerance level $(0,05 \mathrm{mg} / \mathrm{kg})$. Applications during spring, even at the relatively high dosage used, can therefore be safely recommended.

The fermentation curves of grape musts from the aldicarb and fenamiphos treatments as well as untreated controls, are shown in Fig. 2.
After approximately ten days fermentation of all must samples was completed. The low concentrations of the nematicides present in grapes during harvest had no effect on fermentation. These results confirm present findings regarding the applicability of spring applications.

\section{Soil Texture:}

Results of the soil analyses for particle size and clay content are shown in Table 4.

Soil used in the experiment was low in organic matter and fairly homogeneous with depth. No restrictive layers or abnormal $\mathrm{pH}$ values were found. This suggests that the root distribution and nematicide movement were unrestricted.

\section{CONCLUSIONS}

Results of the root distribution study at Vaalharts show that most grape-vine roots occur in the top $600 \mathrm{~mm}$ of soil and are found within $600 \mathrm{~mm}$ of the vine trunk. In order to enhance nematode control on grapevines, it seems essential that the present method of applying nematicides in South Africa should be altered to include the berm area. Nematode control through contact with the only registered nematicide on grape-vine in South Africa, viz. aldicarb, commences within one day following application and lasts for at least 42 days, providing that $0,16 \mathrm{mg} / \mathrm{kg}$ aldicarb is effective in controlling nematodes. Provided that residues in grapes are not increased to unacceptable levels, the feasability of split applications during spring must be examined. Fenamiphos, on the other hand, provide prolonged 
TABLE 4

Soil texture with depth of a loamy sand $(\mathrm{pH} 5,7)$ in Vaalharts.

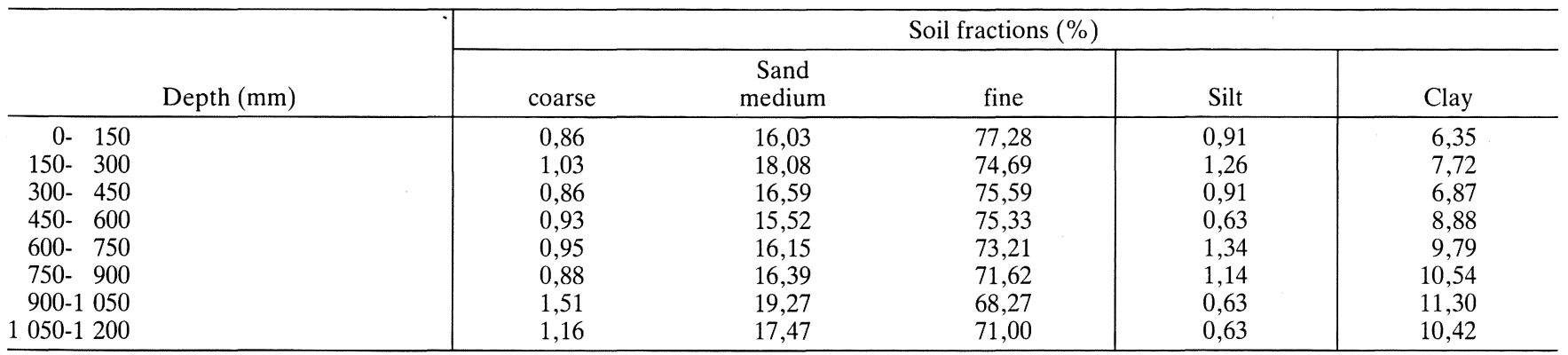

protection under similar conditions. However, because of the lower solubility and leaching ability of fenamiphos, more water should be applied at the time of treatment as well as during the period of root growth.

Root growth observations have shown that two periods of root development occur annually. For the protection of new root tips against penetration by nematodes, nematicide application should therefore ideally be made after harvest as well as at time of budburst.

Taking residues of nematicides in leaves as a measure of the speed of uptake and systemic action in the vine, it was shown that aldicarb acted within the plant after three days and fenamiphos after ten days. As a repellent for invading larvae, it is therefore evident that the timing of application for both chemicals and especially in the case of fenamiphos, is critical. Different application methods of aldicarb have also shown varied nematicide uptake by the plant. The movement and action of this nematicide within the root system of grape-vines must be determined in order to make final decisions regarding the placement of the chemical in vineyards.

The present results provide further evidence of the varied aspects involved in successful chemical control of nematodes. The information at hand provides for the formulation of improved strategies for root-knot nematode control in established vineyards although some facts still have to be clarified.

\section{LITERATURE CITED}

ANDRAWES, N.R., BAGLEY, W.P. \& HERRETT, R.A., 1971. Fate and carry-over properties of Temik aldicarb pesticide (2methyl-2-(methylthio) propionaldehyde 0 -(methyl carbamoyl oxime) in soil. J. Agric. Food Chem. 19, 727-730.

ATILANO, R.A. \& VAN GUNDY, S.A., 1979. Effects of some systemic non-fumigant and fumigant nematicides on grape mycorrhizae fungi and citrus nematode. Pl. Dis. Reptr 63, 729-733.

BRODIE, D.B., 1971. Differential vertical movement of non-volatile nematicides in soil. J. Nematol. 63, 292-295.

BROMILOW, R.H., 1973. Breakdown and fate of oxime carbamate nematicides in crops and soils. Ann. Appl. Biol. 75, 473-479.

CAREY, W.F. \& HELRICH, K., 1970. Improved quantitative method for the determination of aldicarb and its oxidation products in plant material. J. Assoc. Off. Anal. Chem. 53, $1296-1299$.

CONRADIE, W.J., 1980. Seasonal uptake of nutrients by Chenin blanc in sand culture: I. Nitrogen. S. Afr. J. Enol. Vitic. 1, 59-65.

CUANY, A., LAVERGNE, J.C., TRUEL, P.C. \& RENNES, C., 1979. Activité relative de quelques nématicides dans la lutte contre le nématode Meloidogyne arenaria de Vitis vinifera. Progr. Agric. Vitic. 96, 430-432.

CUANY, A., LAVERGNE, J.C. \& PISTRE, R., 1980. Action nématicide de l'aldicarbe et du sulfocarbe contre le nématode $X i$ phinema index en vignoble. Progr. Agric. Vitic. 97, 126-129.

DEN OUDEN, H., 1971. De ontwikkeling van Heterodera rostochiensis larven in aardappelwortels bij behandeling met systemische nematiciden in het bijzonder aldicarb. Meded. Fac. Landbouwet. Rijksuniv. Gent, 36, 889-903.
FLINT, D.R., 1977. Chemical evidence for systemic nematicidal activity of Nemacur. Pflanzenschutz-Nachrichten Bayer 30, 153-163.

FREEMAN, B.M. \& SMART, R.E., 1976. A root observation laboratory for studies with grapevines. Am. J. Enol. Vitic. 27, 36-39.

GRIFFIN, G.D., 1978. Soil moisture; the life blood of aldicarb and its control of the sugarbeet cyst nematode. Utah Science 39, $59-61$.

HAFEZ, S.L. \& RASKI, D.J., 1981. Residue dynamics and persistence of aldicarb and its biologically similar active metabolites in grapevines. J. Nematol. 13, 29-36.

HAFEZ, S.L., RASKI, D.J. \& LEAR, B., 1981. Action of systemic nematicides in control of Xiphinema index of grape. J. Nematol. 13, 24-29.

HILD, J. \& THIER, H.P., 1978. Analysenmetode für rückstände der thioäther, sulfoxide und sulfone van organophosphor-pesticiden in pflanzenmaterial. Z. Lebensm. Unters.-Forsch. 166, 9-12.

HOMEYER, B., 1971. Nemacur, a highly effective nematicide for protective and curative application. Pflanzenschutz-Nachrichten Bayer 24, 48-68.

HOMEYER, B. \& WAGNER, K., 1981. Mode of action of fenamiphos and its behaviour in soil. Nematologica 27, 215-219.

HOUGH, A. \& THOMASON, I.J., 1975. Effects of aldicarb on the behaviour of Heterodera schachtii and Meloidogyne javanica. $J$. Nematol. 7, 211-229.

HOUGH, A., THOMASON, I.J. \& FARMER, W.J., 1975. Behaviour of aldicarb in soil relative to control of Heterodera schachtii. J. Nematol. 7, 214-211.

IWATA, Y., WESTLAKE, W.E., BARKLEY, J.H., CARMEN, G.E. \& GUNTHER, F.A., 1977. Aldicarb residues in oranges, citrus by-products, orange leaves, and soil after an aldicarb soilapplication in an orange grove. J. Agric. Food Chem. 25, 933-936.

KRAUSE, M., LOUBSER, J.T. \& DE BEER, P.R., 1986. Residues of aldicarb and fenamiphos in soil, leaves and fruit from a treated vineyard. J. Agric. Food Chem. 34, 717-720.

LOUBSER, J.T. \& DE KLERK, C.A., 1986. Chemical control of nematodes in established vineyards. S. Afr. J. Enol. Vitic. 6, 31-33.

McKENRY, M.V., 1984. Grape root phenology relative to control of parasitic nematodes. Am. J. Enol. Vitic. 35, 206-211.

NELMES, A.J. \& KEERWEEWAN, S., 1970. The mechanism of action of aldicarb in controlling root-knot nematodes, Meloidogyne incognita, on tomatoes. In Proc. 7th International Congress of Plant Protection, Paris, 21-25 September 1970, 182-183.

PRATT, C., 1974. Vegetative anatomy of cultivated grapes - A review. Am. J. Enol. Vitic. 25, 131-150.

RAJENDRAN, G. \& NAGANATHAN, T.G., 1978. Control of root-knot nematodes in grapes. Vitis 17, 271-273.

RASKI, D.J., JONES, N.O., HAFEZ, S.L., KISSLER, J.J. \& LUVISI, D.A., 1981. Systemic nematicides tested as alternatives to DBCP. Calif. Agric. May - June, 11-12.

RICHARDS, D., 1983. The grape root system. Hort. Rev. 5, $127-168$.

STIRLING, G.R., 1982. Nematicides in vineyards: possible alternatives to DBCP. Australian Grapegrower and Winemaker, April, 1985.

VAN ZYL, J.L., 1984. Response of Colombar grape-vines to irrigation as regards quality aspects and growth. S. Afr.J. Enol. Vitic. 5, 19-28.

WHITEHEAD, A.G., 1973. Control of cyst-nematodes (Heterodera spp.) by organophosphates, oximecarbamates and soil fumigants. In Proc. of the Association of Applied Biologists, London, 6 February, 1973, 439-453. Ann. appl. Biol. 75. 